\title{
Inculcating Patriotic Values in Curriculum Implementation
}

\author{
Dr. Ikhsan Othman \\ Faculty of Education and Human Development, Sultan Idris Education University, Malaysia
}

\begin{abstract}
Tremendous world development and globalization to some extent affect declination of patriotic values among younger generation. To teachers, this phenomenon becomes a great challenge. This article discusses findings of a study on teacher's perception regarding with factors affecting effort of inculcating patriotic values in curriculum implementation. A total of 45 male and 50 female teachers were involved in the study as respondents. Data were collected from the respondents using a four level Likert scale questionnaire consist of 30 items. The items were under five categories of factors namely curriculum; teaching and learning resources; teachers' knowledge; teachers' own skills; and teachers' teaching workload. Reliability of the questionnaire was calculated and has the value $\alpha=.88$. The validity of the questionnaire was ascertained with external criticsm method. Data were analyzed descriptively using mean scores to illuminate the stipulated research questions. The findings of the study shows, teacher's percept that curriculum; teaching and learning resources; teachers' knowledge; teachers' own skills; and teachers' teaching workload have strong relationship with the effort of inculcating patriotic values in curriculum implementation. Further analyses using inferential statistic T-Test shows that there was no significant difference between male teachers' perception and female teachers' perception; which mean that they collectively admit that there is a strong relationship between the factors with the effort of inculcating patriotic values in their teaching and learning processes.
\end{abstract}

Keywords: Inculcating, patriotic values, curriculum implementation.

\section{Introduction}

Generally patriotism means loving one's nation and to defend its sovereignty. Patriotism can also means a sense of loyalty, obligations and responsibilities to the nation and to ensure it remains free and independent from any form of colonialism. The spirit of patriotism is vital in every citizen of an independent nation as patriotism is catalyst for nation building. In most countries, patriotism is one of the values that have to be inculcated through their education system that is in curriculum and its implementatuion. Patriotic values were inculcated in teaching and learning processes to nurture and nourish their spirit of love for their homeland. This is base on a principle that youths of today are citizens of tomorrow. Therefore teachers have a big role to play especially in schools and classrooms to assure the insertion of the values become realistic and significant. Curriculum activities to inculcate positive attitudes, nurture good characters and pleasant personality should be planned. Activities involving moral and spiritual appreciation and activities based on healthy lifestyles would help in the formation of self-worth among students.

\section{Research Background}

In light of the preceding discussion, this study aimed to identify teachers' perception on the relationship between curriculum; teaching and learning resources; teachers' knowledge; teachers' own skills; and teaching workload with the effort of inculcating patriotic values in curriculum implementation that is in teaching and learning processes.

\section{Research Questions}

The research questions in this study are as follows.

a) How is teacher's perception on the relationship between curriculum and the effort to inculcate patriotic values in their teaching and learning processes?

b) How is teacher's perception on the relationship between teaching and learning resources and the effort to inculcate patriotic values in their teaching and learning processes?

c) How is teacher's perception on the relationship between teachers' knowledge and the effort to inculcate patriotic values in their teaching and learning processes?

d) How is teacher's perception on the relationship between their own skills and the effort to inculcate patriotic values in their teaching and learning processes?

e) How is teacher's perception on the relationship between teachers' teaching workload and the effort to inculcate patriotic values in their teaching and learning processes? 


\section{Research Hypotheses}

Specifically null hypotheses for this study are as follows.

a. There is no significant difference between male teachers' perception and female teachers' perception about the relationship between curriculum and the effort to inculcate patriotic values in their teaching and learning processes.

b. There is no significant difference between male teachers' perception and female teachers' perception about the relationship between teaching and learning resources and the effort to inculcate patriotic values in their teaching and learning processes.

c. There is no significant difference between male teachers' perception and female teachers' perception about the relationship between teachers' knowledge and the effort to inculcate patriotic values in their teaching and learning processes.

d. There is no significant difference between male teachers' perception and female teachers' perception about the relationship between their own skills and the effort to inculcate patriotic values in their teaching and learning processes.

e. There is no significant difference between male teachers' perception and female teachers' perception about the relationship between teachers' teaching workload and the effort to inculcate patriotic values in their teaching and learning processes.

\section{Methodology}

This study aims to identify teachers' perception on the relationship between curriculum; teaching and learning resources; teachers' knowledge; teachers' own skills; and teaching workload with the effort of inculcating patriotic values in their teaching and learning processes in curriculum implementation. Survey method was used with a questionnaire developed by researcher as the research instrument. The instrument was organized with five subscales namely curriculum; teaching and learning resources; teachers' knowledge; teachers' own skills; and teaching workload. Respondents response to the questionnaire with four level Likert scale 1=Strongly Not Agree, 2=Not Agree, 3=Agree and 4=Strongly Agree. The instrument consists of 30 items. Reliability of the instrument was calculated and has the value $\alpha=.88$. The validity of the instrument was ascertained with the method of external critics. Overall the instrument has relevant quality for this study. The questionnaire was distributed to a total of 100 teachers comprised of 50 males and 50 females' teachers to get their responses. Only 45 males and 50 females teachers returned the questionnaire.

\section{Data Analyzes and Findings}

When the questionnaire had been collected, it was processed and the data were analyzed. Data were analyzed descriptively using mean scores to illuminate the research questions.

Research Question (a): How is teacher's perception on the relationship between curriculum and the effort to inculcate patriotic values in their teaching and learning processes?

Ho (1): There is no significant difference between male teachers' perception and female teachers' perception about the relationship between curriculum and the effort to inculcate patriotic values in their teaching and learning processes.

To illuminate Research Question (a) and to examine Ho (1), datasets from the questionnaire were analyzed and the findings are summarized in Table 1 and Table 2. Table 1 shows the mean score for each item in the questionnaire regarding with teacher's perception on the relationship between curriculum and the effort to inculcate patriotic values in their teaching and learning processes. Table 2 shows the T-Test result from the data analysis.

TABLE 1: Mean Scores Teachers' Perception On The Relationship Between Curriculum And The Effort To Inculcate Patriotic Values

\begin{tabular}{|c|c|c|c|}
\hline $\begin{array}{l}\text { Items } \\
\text { No. }\end{array}$ & Items & $\begin{array}{c}\text { Mean } \\
\text { Scores } \\
(\mu)\end{array}$ & $\begin{array}{c}\text { Standard } \\
\text { Deviation } \\
(\sigma)\end{array}$ \\
\hline 19. & Patriotic values should be integrated across curriculum and curriculum implementation. & 3.42 & .678 \\
\hline 20. & $\begin{array}{l}\text { Related patriotic values to be integrated are better to be suggested in curriculum } \\
\text { documentations. }\end{array}$ & 3.57 & .595 \\
\hline 21. & The objectives of inculcating patriotic values in curriculum should be specified clearly. & 3.49 & .666 \\
\hline 22. & $\begin{array}{l}\text { The methods of inculcating patriotic values should be suggested in curriculum } \\
\text { documentations. }\end{array}$ & 3.54 & .598 \\
\hline 23. & Suggested learning activities to inculcate patriotic values in curriculum implementation & 3.59 & .592 \\
\hline
\end{tabular}




\begin{tabular}{|l|l|r|r|}
\hline & should be given. & & \\
\hline 24. & Inculcating patriotic values in curriculum should be revised from time to time. & 3.45 & .632 \\
\hline & \multicolumn{1}{|l|}{ Overall } & 3.51 & .272 \\
\hline
\end{tabular}

1=Strongly Not Agree, 2=Not Agree, 3=Agree and 4=Strongly Agree

TABLE 2: T-Test To Determine The Difference Between Mean Score Of Male Teachers' Perception And Female Teachers' Perceptions

\begin{tabular}{|c|c|c|c|c|c|}
\hline Gender & $\mathrm{N}$ & Mean Score & SD & $\mathrm{t}$ & $\mathrm{p}$ \\
\hline Male & 45 & 3.51 & .297 & .145 & 0.885 \\
\cline { 2 - 6 } Female & 50 & 3.51 & .250 & & \\
\hline
\end{tabular}

Table 1 shows the result of the data analysis to answer Research Question (a). Overall, mean score $(\mu=3.51$, $(\sigma=.272)$ is in the range of "Agree" and "Strongly Agree". From Table 2, the value $t=.145(p=0.885)$ shows that there is statistically no significant difference at $\mathrm{p} \leq .05$ between male teachers' perception and female teachers' perception on the relationship between curriculum and the effort to inculcate patriotic values in their teaching and learning processes. Therefore the null hypotheses $\mathrm{Ho}(1)$ failed to be rejected. From these findings, conclusion can be drawn that teachers as respondents in this study collectively admit that there is a relationship between curriculum and the effort to inculcate patriotic values in their teaching and learning processes.

Research Question (b): How is teacher's perception on the relationship between teaching and learning resources and the effort to inculcate patriotic values in their teaching and learning processes?

Ho(2): There is no significant difference between male teachers' perception and female teachers' perception about the relationship between teaching and learning resources and the effort to inculcate patriotic values in their teaching and learning processes.

To illuminate Research Question (b) and to examine $\mathrm{Ho}(2)$, datasets from the questionnaire were analyzed and the findings are summarized in Table 3 and Table 4. Table 3 shows mean score for each item in the questionnaire regarding with teacher's perception about relationship between teaching and learning resources and the effort to inculcate patriotic values in their teaching and learning processes. Table 4 shows the $\mathrm{T}$-Test result from the data analysis.

TABLE 3: Mean Scores Teachers' Perception On The Relationship Between Teaching And Learning Resources And The Effort To Inculcate Patriotic Values

\begin{tabular}{|c|c|c|c|}
\hline $\begin{array}{l}\text { Items } \\
\text { No. }\end{array}$ & Items & $\begin{array}{c}\text { Mean } \\
\text { Scores } \\
(\mu)\end{array}$ & $\begin{array}{c}\text { Standard } \\
\text { Deviation } \\
(\sigma)\end{array}$ \\
\hline 13. & $\begin{array}{l}\text { Teaching and learning resources are important for inculcation of patriotic values in } \\
\text { curriculum. }\end{array}$ & 3.56 & .560 \\
\hline 14. & $\begin{array}{l}\text { Schools should have resource centre for better management of the resources regarding with } \\
\text { patriotic values. }\end{array}$ & 3.45 & .665 \\
\hline 15. & $\begin{array}{l}\text { Schools should provide adequate teaching and learning resources for integration of } \\
\text { patriotic values in teaching and learning processes. }\end{array}$ & 3.51 & .599 \\
\hline 16. & Students' exposure to resources should be done to promote their patriotic values. & 3.56 & .578 \\
\hline 17. & $\begin{array}{l}\text { Teachers can use relevant teaching and learning resources in their teaching and learning } \\
\text { processes to promote patriotic values in their teaching and learning processes. }\end{array}$ & 3.54 & .616 \\
\hline \multirow[t]{2}{*}{18.} & $\begin{array}{l}\text { It is better to have workshops among teachers on how to make use of learning resources to } \\
\text { inculcate patriotic values in their teaching and learning processes. }\end{array}$ & 3.42 & .752 \\
\hline & Overall & 3.51 & .283 \\
\hline
\end{tabular}

1=Strongly Not Agree, 2=Not Agree, 3=Agree and 4=Strongly Agree

TABLE 4: T-Test To Determine The Difference Between Mean Score Of Male Teachers' Perception And Female Teachers' Perceptions

\begin{tabular}{|l|c|c|c|c|c|}
\hline Gender & $\mathrm{N}$ & Mean Score & SD & $\mathrm{t}$ & $\mathrm{p}$ \\
\hline Male & 45 & 3.53 & .263 & .917 & 0.362 \\
\hline Female & 50 & 3.48 & .300 & & \\
\hline
\end{tabular}

Table 3 shows the result of the data analysis to answer the Research Question (b). Overall, mean score $(\mu=3.51$, $\sigma=.283)$ is in the range of "Agree" and "Strongly Agree". From Table 4, the value of $t=.917(p=0.362)$ shows that there is statistically no significant difference at $\mathrm{p} \leq .05$ between male teachers' perception and female teachers' perception on the relationship between teaching and learning resources with the effort to inculcate patriotic values in their teaching and learning processes. Therefore the null hypotheses $\mathrm{Ho}(2)$ failed to be rejected. From these findings, conclusion can be drawn that teachers as respondents in this study collectively 
admit that there is a relationship between teaching and learning resource with the effort to inculcate patriotic values in their teaching and learning processes.

Research Question (c): How is teacher's perception on the relationship between teachers' knowledge and the effort to inculcate patriotic values in their teaching and learning processes?

Ho(3): There is no significant difference between male teachers' perception and female teachers' perception about the relationship between teachers' knowledge and the effort to inculcate patriotic values in their teaching and learning processes.

To illuminate Research Question (c) and to examine $\operatorname{Ho}(3)$, datasets from the questionnaire were analyzed and the findings are summarized in Table 5 and Table 6 . Table 5 shows the mean score for each item in the questionnaire regarding with teacher's perception on the relationship between teachers' knowledge and the effort to inculcate patriotic values in their teaching and learning processes. Table 6 shows the T-Test result from the data analysis.

TABLE 5: Mean Scores Teachers' Perception On The Relationship Between Their Knowledge And The Effort To Inculcate Patriotic Values

\begin{tabular}{|c|c|c|c|}
\hline $\begin{array}{l}\text { Items } \\
\text { No. }\end{array}$ & Items & $\begin{array}{c}\text { Mean } \\
\text { Scores } \\
(\mu)\end{array}$ & $\begin{array}{c}\text { Standard } \\
\text { Deviation } \\
(\sigma)\end{array}$ \\
\hline 1. & Teachers' knowledge on patriotic values needs to be updated from time to time. & 3.33 & .591 \\
\hline 2. & $\begin{array}{l}\text { Teachers need to make extra reading in addition to the textbook before integrating patriotic } \\
\text { values in their teaching and learning processes. }\end{array}$ & 3.25 & .564 \\
\hline 3. & $\begin{array}{l}\text { Teachers need to keep on identifying patriotic values for their teaching and learning } \\
\text { processes. }\end{array}$ & 3.19 & .641 \\
\hline 4. & $\begin{array}{l}\text { Teachers need to know patriotic values to be in parallel with the scope and content of their } \\
\text { teaching and learning processes. }\end{array}$ & 3.16 & .704 \\
\hline \multirow[t]{2}{*}{5.} & $\begin{array}{l}\text { Teachers need to know how to inculcate patriotic values in their teaching and learning } \\
\text { processes. }\end{array}$ & 3.19 & 689 \\
\hline & Overall & 3.21 & .252 \\
\hline
\end{tabular}

1=Strongly Not Agree, 2=Not Agree, 3=Agree and 4=Strongly Agree

TABLE 6: T-Test To Determine The Difference Between Mean Score Of Male Teachers' Perception And Female Teachers' Perceptions

\begin{tabular}{|c|c|c|c|c|c|}
\hline Gender & $\mathrm{N}$ & Mean Score & SD & $\mathrm{p}$ & .691 \\
\hline Male & 45 & 3.23 & .259 & 0.491 \\
\hline Female & 50 & 3.19 & .247 & & \\
\hline
\end{tabular}

Table 5 shows the result of the data analysis to answer the Research Question (c). Overall, mean score $(\mu=3.21$, $\sigma=.252)$ is in the range of "Agree" and "Strongly Agree". From Table 6, the value of $t=.691(\mathrm{p}=0.491)$ shows that there is statistically no significant difference at $\mathrm{p} \leq .05$ between male teachers' perception and female teachers' perception on the relationship between teachers' knowledge and the effort to inculcate patriotic values in their teaching and learning processes. Therefore the null hypotheses Ho(3) failed to be rejected. From these findings, conclusion can be drawn that teachers as respondents in this study collectively admit that there is a relationship between teachers' knowledge and the effort to inculcate patriotic values in their teaching and learning processes.

Research Question (d): How is teacher's perception on the relationship of their own skills and the effort to inculcate patriotic values in their teaching and learning processes?

Ho(4): There is no significant difference between male teachers' perception and female teachers' perception about the relationship between their own skills and the effort to inculcate patriotic values in their teaching and learning processes.

To illuminate Research Question (d) and to examine $\mathrm{Ho}(4)$, datasets from the questionnaire were analyzed and the findings are summarized in Table 7 and Table 8 . Table 7 shows the mean score for each item in the questionnaire regarding with teacher's perception on the relationship between their own skills and the effort to inculcate patriotic values in their teaching and learning processes. Table 8 shows the T-Test result from the data analysis. 
TABLE 7: Mean Scores Teachers' Perception On The Relationship Between Their Own Skills And The Effort To Inculcate Patriotic Values

\begin{tabular}{|c|c|c|c|}
\hline $\begin{array}{l}\text { Items } \\
\text { No. }\end{array}$ & Items & $\begin{array}{c}\text { Mean } \\
\text { Scores } \\
(\mu)\end{array}$ & $\begin{array}{c}\text { Standard } \\
\text { Deviation } \\
(\sigma)\end{array}$ \\
\hline 7. & Teaching skills are important for inculcation of patriotic values in curriculum. & 3.17 & .724 \\
\hline 8. & $\begin{array}{l}\text { Teachers must have skills to identify the relevant patriotic values to be inculcated in their } \\
\text { their teaching and learning. }\end{array}$ & 3.20 & .723 \\
\hline 9. & $\begin{array}{l}\text { Teachers' skills for inculcating patriotic values in teaching and learning processes are } \\
\text { important. }\end{array}$ & 3.19 & .719 \\
\hline 10. & Teachers' should have skills to evaluate students' patriotism. & 3.22 & .671 \\
\hline 11 & $\begin{array}{l}\text { Teachers should have skills to get relevant sources to support activities inculcating patriotic } \\
\text { values. }\end{array}$ & 3.13 & .703 \\
\hline \multirow[t]{2}{*}{12} & $\begin{array}{l}\text { Teachers' skills for inculcating patriotic values among their students need to be updated } \\
\text { from time to time. }\end{array}$ & 3.22 & .607 \\
\hline & Overall & 3.22 & .296 \\
\hline
\end{tabular}

1=Strongly Not Agree, 2=Not Agree, 3=Agree and 4=Strongly Agree

TABLE 8: T-Test To Determine The Difference Between Mean Score Of Male Teachers' Perception And Female Teachers' Perceptions

\begin{tabular}{|c|c|c|c|c|c|}
\hline Gender & $\mathrm{N}$ & Mean Score & SD & $\mathrm{t}$ \\
\hline Male & 45 & 3.21 & .342 & -.030 & 0.976 \\
\hline Female & 50 & 3.22 & .250 & & \\
\hline
\end{tabular}

Table 7 shows the result of the data analysis to answer the Research Question $(d)$. Overall, mean score $(\mu=3.22$, $\sigma=.296)$ is in the range of "Agree" and "Strongly Agree". From Table 4, the value of $t=-.030(p=0.976)$ shows that there is statistically no significant difference at $\mathrm{p} \leq .05$ between male teachers' perception and female teachers' perception on the relationship between their own skills and the effort to inculcate patriotic values in their teaching and learning processes. Therefore the null hypotheses Ho(4) failed to be rejected. From these findings, conclusion can be drawn that teachers as respondents in this study collectively admit that there is a relationship between teachers' own skills and the effort to inculcate patriotic values in their teaching and learning processes.

Research Question (e): How is teacher's perception on the relationship between teachers' teaching workload and the effort to inculcate patriotic values in their teaching and learning processes?

Ho(5): There is no significant difference between male teachers' perception and female teachers' perception about the relationship between teachers' teaching workload and the effort to inculcate patriotic values in their teaching and learning processes.

To illuminate Research Question (e) and to examine Ho(5), datasets from the questionnaire were analyzed and the findings are summarized in Table 9 and Table 10. Table 9 shows the mean score for each item in the questionnaire regarding with teacher's perception about relationship between teachers' teaching workload and the effort to inculcate patriotic values in their teaching and learning processes. Table 10 shows the T-Test result from the data analysis.

TABLE 9: Mean Scores Teachers' Perception On The Relationship Between Teachers' Teaching Workload And The Effort To Inculcate Patriotic Values

\begin{tabular}{|c|c|c|c|}
\hline $\begin{array}{l}\text { Items } \\
\text { No. }\end{array}$ & Items & $\begin{array}{c}\text { Mean } \\
\text { Scores } \\
(\mu)\end{array}$ & $\begin{array}{c}\text { Standard } \\
\text { Deviation } \\
(\sigma)\end{array}$ \\
\hline 25. & $\begin{array}{l}\text { Teachers' teaching workload should be reduced to make way for teachers inculcating } \\
\text { patriotic values in curriculum implementation. }\end{array}$ & 3.32 & .733 \\
\hline 26. & $\begin{array}{l}\text { Less teaching workload among teachers will contribute to the enhancement of inculcating } \\
\text { patriotic values. }\end{array}$ & 3.17 & .739 \\
\hline 27. & $\begin{array}{l}\text { Most teachers have adequate teaching workload to make way for inculcation of patriotic } \\
\text { values. }\end{array}$ & 3.09 & .730 \\
\hline 28. & $\begin{array}{l}\text { Inculcation of patriotic values in curriculum implementation does not bring extra workload } \\
\text { to teachers. }\end{array}$ & 3.13 & .733 \\
\hline 29. & $\begin{array}{l}\text { Teacher should understand that inculcating patriotic values in curriculum implementation } \\
\text { is part and partial of their jobs }\end{array}$ & 3.16 & .734 \\
\hline \multirow[t]{2}{*}{30.} & $\begin{array}{l}\text { Inculcating patriotic values in curriculum implementation considered as main requirements } \\
\text { compared to other workload. }\end{array}$ & 3.05 & .735 \\
\hline & Overall & 3.15 & .360 \\
\hline
\end{tabular}

1=Strongly Not Agree, 2=Not Agree, 3=Agree and 4=Strongly Agree 
TABLE 10: T-Test To Determine The Difference Between Mean Score Of Male Teachers' Perception And Female Teachers' Perceptions

\begin{tabular}{|c|c|c|c|c|c|}
\hline Gender & $\mathrm{N}$ & Mean Score & SD & $\mathrm{t}$ & $\mathrm{p}$ \\
\hline Male & 45 & 3.19 & .367 & 1.026 & 0.308 \\
\hline Female & 50 & 3.12 & .354 & & \\
\hline
\end{tabular}

Table 9 shows the result of the data analysis to answer the Research Question (e). Overall, mean score $(\mu=3.15$, $\sigma=.360)$ is in the range of "Agree" and "Strongly Agree". From Table 10, the value of $t=1.026(p=0.308)$ shows that there is statistically no significant difference at $\mathrm{p} \leq .05$ between male teachers' perception and female teachers' perception on the relationship between teachers' teaching workload and the effort to inculcate patriotic values in their teaching and learning processes. Therefore the null hypotheses $\mathrm{Ho}(5)$ failed to be rejected. From these findings, conclusion can be drawn that teachers as respondents in this study collectively admit that there is a relationship between teachers' teaching workload and the effort to inculcate patriotic values in their teaching and learning processes.

\section{Conclusion, Discussion and Suggestion}

This study is about inculcating patriotic values in curriculum implementation. The study focused on teachers' perception regarding with factors affecting the effort of inculcating patriotic values in curriculum implementation. The findings of the study show that teachers as the respondents collectively admit that there is a relationship between curriculum; teaching and learning resources; teachers' knowledge; teachers' own skills; and teachers' teaching workload with the effort to inculcate patriotic values in their teaching and learning processes. The findings in this study are in parallel with the findings of a study by Sophist Sanguan (2009).

Several assertions can be made based on the findings. From the findings of the study about teachers' teaching workload, actions should be taken to deal with this matter. Suggestion such as giving appropriate number of hours in teachers' teaching time table will reduce teachers' teaching workload. Thus, more focus or concentration expected to be given by teachers for inculcation of patriotism if teachers have less workload. By doing so hopefully the inculcation of patriotic values in curriculum implementation will be successful and meet the target of producing quality nation state for nation development.

This study investigates teachers' perception on the factors affecting the effort of inculcating patriotic values in curriculum implementation. The study was limited to five main aspects namely curriculum; teaching and learning resources; teachers' knowledge; teachers' own skills; and teachers' teaching workload. As for further research, it is suggested to broaden the aspects to acquire broader perspective about the smoothness of inculcating patriotic values in curriculum implementation. It is also suggested to have larger sample size to produce a representative sample which will allow generalization to be made for wider population.

\section{References}

[1]. Abd Rahim Abd Rashid (2004). Patriotisme agenda pembinaan bangsa. Kuala Lumpur: Utusan Publication Sdn. Bhd.

[2]. Ikhsan Othman (2010). Fenomena dalam masyarakat dan pendekatan menangani melalui pendidikan. Social and Welfare Journal. Vol.36.page 1-16.

[3]. Malaysia Ministry of Education (2006). Education Development Master Plan (2006-2010). Kuala Lumpur: Ministry of Education

[4]. Muhamad Ali Embi (2009). Patriotisme dan kepercayaan rakyat di Malaysia. Kuala Lumpur: Utusan Publication Sdn. Bhd.

[5]. Norila Md Salleh \& Ikhsan Othman (2013). Globalization via ICT: Impact on the Youth in Making of a Nation State. Journal International Affairs and Global Strategy. Vol.17. 2013. Page 20-24.

[6]. Primoratz, I. \& Pavkovic, A. (2007). Patriotism philosophical and political perspectives. England: Aldershot.

[7]. Sophist Sanguan (2009). Masalah penerapan nilai patriotisme dalam pengajaran Sejarah. Masters Degree Project Paper Report. Sultan Idris Education University. 